AUTHOR:

Prof Mariëtte Koen ${ }^{1}$

AFFILIATION:

${ }^{1}$ North-West University

Potchefstroom

DOI: http://dx.doi. org/10.18820/2519593X/pie. v40.i1.19

e-ISSN 2519-593X

Perspectives in Education

2021 39(4): 323-325

PUBLISHED:

04 March 2022

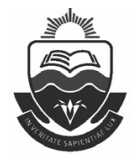

Published by the UFS http://journals.ufs.ac.za/index.php/pie

(-) Creative Commons With Attribution (CC-BY)

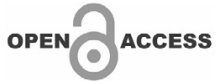

\section{Teaching in and beyond pandemic times}

\section{A book review by Prof Mariëtte Koen}

With more than 230 million cases of COVID-19 having been confirmed worldwide to date, the economic, social and mental disruption of the pandemic has left its mark on virtually every aspect of human development. The resulting school closures have likewise brought significant disruptions in education systems and in teaching programmes all over the world. South Africa has certainly been no exception and the loss of access to formal education has plunged our schools into a major teaching and learning crisis. Not only has this pandemic given rise to backlogs in terms of teaching and learning, but it has also exposed challenges in respect of inequality. Renowned researcher, Professor Jonathan Jansen, and the Fulbright Scholar, Emily O'Ryan, of Stellenbosch University captured learners' experiences regarding pandemic learning in their publication entitled Learning under lockdown. The themes shared in this publication foregrounded that learners and teachers had been affected by COVID-19. This finding prompted Jansen and Farmer-Phillips to publish a second book entitled Teaching in and beyond pandemic times in which these authors share with readers an awareness of teachers' lives during COVID-19. In the foreword, Jansen points out that the purpose was not to publish a standard academic book referring to research elements, but rather to use a narrative form to capture teachers' stories while simultaneously dealing with issues peculiar to distance learning: maintaining effective contact with learners; finding inventive ways of dealing with unequal learner access to reliable data and devices; the effects - on the transition to online learning - of varying and age-related levels of technological competence present among teachers; post-lockdown emotional consequences to teachers of re-entry into the system and teacher deployment in cases where colleagues with comorbidities are allowed to work from home.

In aiming to address the above issues, the editors use five chapters to allow the reader to experience at first-hand what teaching during a lockdown entails. This book, however, does more than merely foreground online 
teaching as such. The strength of the book lies in the way it highlights the importance of the holistic learning and development of teachers amid a pandemic. It becomes clear that, while teachers have had to focus on developing learners' cognitive skills, they have moreover had to be mindful of their own and the learners' emotional, social and physical needs. Little surprise that the editors arrived at the important conclusion that changes in the educational landscape brought about by the pandemic have guaranteed that "teachers cannot simply resume business as usual".

In the first of the five chapters, David J Millar (former District Superintendent/Director of the Western Cape Education Department) pays a tribute to South African teachers by emphasising how the virus disrupted just about every facet of teachers' lives. Without any warning or training, and with little support, teachers were forced to transition from contactlearning environments to virtual-learning environments. Millar describes this overwhelming transition process that required teachers to be innovative, to develop new technological skills and to assist the learners while fulfilling various roles such as spouse, partner, advisor and Zoom controller. Readers cannot but feel obligated to applaud the way teachers went to incredible lengths to function as human beings and teachers.

In the second chapter, Erin Chothia-Lakay (Fairbairn College Goodwood), dedicates a poem to teachers entitled Behind closed doors. Although this poem captures an individual experience during the lockdown situation, readers are taken on a personal journey designed to make them understand the emotional exhaustion brought on by a range of feelings such as uncertainty, anger, fear, despair, restlessness, guilt, sadness and hope. This poem will force readers to pause, reflect and gain insight into their own lockdown experiences. The poem ends by embracing the human condition. While the poem reveals the author's emotions as she goes through episodes of upheaval while fulfilling the role of Erin, daughter, sister, wife, mom, aunt, friend, teacher and colleague, in the end she assures readers that she found solace by accepting - behind closed doors - that she is, after all, only human. The poem may inspire readers to start anew with eagerness, hope, joy and care for others behind their closed doors.

In Chapter 3, co-editor Theola Farmer-Phillips (Yellowwood Primary School, Western Cape), as a practising teacher, shares her perspectives on the lockdown. The reader experiences how prayers gave her strength to find comfort and hope while navigating her commitments through the COVID-19 storm. It is described how the dual role of being a mother at home and a teacher in the Cape Flats made her feel unrecognised and caused feelings of apprehension. In addition, the equity challenges of social distancing in the community, the lack of a sanitising protocol and parents' lack of either resources or education contributed to her feelings of fear and anxiety. However, despite these gruelling circumstances, the reader can celebrate with the author as she ends the chapter with the words: "I am grateful for the lessons brought along, but most of all, I remain grateful for the gift of life".

In Chapter 4, the editors use a cluster of 11 topics as they share a structured collection of 65 teachers' pandemic stories. These stories reveal how the pandemic made teachers feel simultaneously vulnerable and valued while they had to focus on the present and the future of teaching. Like the word pandemic, each of the 11 topics start with the letter $p$, and the concepts pliability, procurement and persistence serve to tie all the stories together in the face of a deadly virus. The topics are pressure; pedagogy; preparation; pioneers; poverty; privilege; perspective; parents and parent teachers; peer teaching; perseverance and pastoral care. 
The final chapter concludes with a summary of ten key lessons learnt from the teachers' stories in the book. It seems the editors want readers to be reminded of how South African teachers navigated the uncertain waters during a pandemic, but that they also mean to stimulate readers' thoughts regarding what an equitable and resilient education system could look like. It is highlighted that learners should no longer be seen as empty vessels waiting to be filled with knowledge. The reader's attention is focused on the fact that the time has come to revise and plan the curriculum-assessment policy statements so as not only to lessen the teachers' workload, but also to make learning more meaningful to the learners. The idea of collaboration between teachers, parents, colleagues, peers and district offices with a view of improving quality teaching is promoted in these lessons. The important theme that runs throughout the book, namely that teachers are frontliners, is especially evident on the last page of the publication where the editors point out that the "sudden lockdown of the nation and its schools could have [had] more catastrophic social and educational consequences ... [had] it not [been] for the teachers and their sacrifices".

This edition of Teaching in and beyond pandemic times, dealing as it does with the lives of teachers during and immediately after the pandemic lockdown, will be of interest to everyone. The book succeeds not only in demonstrating to readers the nature of teaching and learning during a pandemic, but also how South African teachers emerged as champions and why we owe them a debt of gratitude.

Authors: Jonathan D Jansen \& Theola Farmer-Phillips

ISBN (paper): 978-1-928314-01-1

eBook edition: 978-1-928314-49-3 